\title{
Ex-Prisoners, Correctional System, and National Resilience
}

\author{
Rili Windiasih ${ }^{1}$ and Hariyadi Hariyadi ${ }^{2}$ \\ ${ }^{1}$ Postgraduate Program, ${ }^{2}$ Department of Sociology \\ Jenderal Soedirman University \\ Purwokerto, Indonesia \\ rili_msi@yahoo.com
}

\begin{abstract}
The article discusses how ex-prisoners socialized in correctional facility under correctional system could integrate harmoniously into society, and the relevance of ex-prisoners' socialization under correctional system to national resilience. The objective of the research is to find the way to optimize prisoner socialization to support national resilience purposes. Based on a study in correctional facility in Purwokerto, it was found that the institution has conducted prisoner socialization under correctional system in accordance with Act No. 12/1995 on Correctional and associated rules. The study was undertaken by qualitative method with interviews and focused-group discussion. By using some indicators, ex-prisoner who had socialization in the correctional facility are able to integrate harmoniously in their society. It means that they are accepted in everyday life in the society. However, they have difficulties when they look for job. Their societies tend to not recruiting them. Acceptance of exprisoner is affected by several factors, which are not under correctional facility's responsibility. The factors are: kind of crime conducted, socioeconomic status, education status, behaviour before conducting crime, response of victim, and stigma from society to the ex-prisoners. In-depth analysis on prisoner socialization in national resilience perspective concluded that socialization in the system of correctional is in accordance with and support national resilience as stipulated in the Act No. $12 / 1995$ and its associated rules. The article recommends synergy between Ministry of Justice and Human Right c.q. Directorate General of Correctional with National Resilience Institute to formulate programs to enhance prisoner socialization and national resilience.
\end{abstract}

Keywords - ex-prisoners; correctional; national resilience; socialization

\section{INTRODUCTION}

Correctional institution is a place to carry out coaching on prisoners by using correctional system. Correctional system is a system to direct, limit, and guide prisoners as Pancasila (Five Principles) based-penitent residents which is implemented in an integrated manner between prison officers, prisoners themselves, and community to improve the quality of the inmates as prisoners in order to realize their mistakes, and to not repeat criminal acts. It also attempts to make the exprisoners be able to actively participate in the development, and to live reasonable as a good and responsible citizen. To prepare the prisoners back in the community as well as to provide guidance within the correctional, there is also coaching activities outside the correctional implemented by Bapas or Balai Pemasyarakatan (Correctional Office). Correctional Office is a technical implementing unit in charge of external coaching to ex-prisoners under and directly responsible to the Head of Regional Office of Ministry of Justice. According to Yunardhani, correctional institution aims to implement the last goal of criminal justice system, which is rehabilitating and resocialisation of law offender as well as supressing crime [1]. Thus, the role of correctional institution should not be overlooked.

Based on preliminary research it appears that Correctional Institutions through their officers and programs have conducted a series of educational activities on prisoners as part of the convict's guidance system. Educational activities include: study groups of A and B, Arabic letters, skills education, spiritual education, agricultural education, plantation and carpentry that in the perspective of education can be categorized as non-formal education or external education. It is said to be a non-formal education because although education has been done deliberately, orderly, and planned, but this educational activity does not have a certain level and time and there is no specific gradation based on official rules. In addition, education activities in correctional institutions are non-formal education is functional and practical and broad-based and integrated with each other ultimately for those who want to be able to follow it freely, although still related to certain rules. For ex-inmates, the coaching is based more on the moral responsibility of the community because they are free. Society is a container as well as participants to restore prisoners in the life of society, nation, and state. However, based on existing literature it is difficult to suggest to public that inmates should not be considered "public waste". The communities in fact still tend to reject the presence of ex-prisoners in their midst as they are much less interested in the process of the return of an exinmate to their neighbourhood. How societies respond to exconvicts needs serious attention in view of their negative impacts even though it could also have positive implications in the context of general deterrence to the public as well as special protection to the perpetrators. And not every exprisoner reacts negatively to the reaction of society. 
The concept of socialization requires the accommodative attitude of society so that the perpetrators can return to live among the community peacefully without carrying the burden and stigma of the community, but on the other hand it is needed as means of social control that are recognized for their effectiveness [2]. Inmates as individuals and citizens of Indonesia have the same rights and obligations as other Indonesian citizens to do something for the benefit of the nation and state. It can be enabled if the prisoners have returned to be a human being with good mentality and quality. It is in this notion that the Correctional Institution is important not only because it is a means of fostering prisoners as human beings in order to improve their ability to live independently in the midst of society but also a facility to provide state awareness education including to know their rights and obligations, obligations. The Correctional Institution is also a Pancasila (Five Principles) implementing unit which plays a role in development, so that it is one of the educational institutions and development institutions [3]. This is in line with the objective of National Resilience in which there are two things to be achieved, that is to be able to maintain the survive and to develop the life of the nation and the state of Indonesia. Thus, the article aims to gain understanding on how and in what ways the objective of National Resilience could be in line with correctional system.

By looking at the above considerations, it is important to look at the guidance of prisoners and ex-prisoners in the perspective of national resilience. The consideration to write a review of the implementation of the guidance in this prisoner is to show the gap between the ide and the reality, and its improvisations. In addition, by looking at the implementation it is expected to improve the implementation. This article will therefore answer the following three questions:

- How is the implementation of guidance of prisoners with correctional system in correctional institution?

- Is fostering prisoners with correctional systems resulted in the harmonious integration when former prisoner returned to society?

- How is the implementation of inmates coaching in the perspective of national resilience?

\section{MethoD}

The location of research for this article was Correctional Institution Class IIB Purwokerto and Correctional Office Purwokerto as well as several places that are included in the region of Banyumas Regency. In this article research method used was qualitative method. The use of qualitative approach methods in this study aims to reveal and gain perceptions and opinions in depth and detail of the research object of the informant [4]. The specification used in this study is descriptive, as it attempts to describe in detail the implementation of guidance of prisoners with correctional systems in prisons; the result of fostering inmates with correctional systems in order for them to be able to return to society and to integrate harmoniously; as well as the implementation of guidance of prisoners in the perspective of national resilience.

Primary data were taken from informants consisting of prisoners, convicted persons who received Pembebasan Bersyarat (PB) or conditional release and Cuti Menjelang Bebas (CMB) or pre-release treatment, Correctional Office and Correctional Institution officials, and the community. Secondary data is drawn from legislation especially Criminal Code, Correctional Law, and documents (data file of officers and prisoners and convicts who obtained $\mathrm{PB}$ and $\mathrm{CMB}$ ), as well as other research results related to the object of this study.

Researchers also observed social situations. Social situations include a description of the situation of the place and space of a social situation; actors in social situations, including their inherent characteristics (such as status, sex, age and so on); the behaviour of actors in the process of activities/ activities in a social situation related to the object of research, among others, in Correctional Institution, as well as in the community where the convicts who get $\mathrm{PB}$ and $\mathrm{CMB}$ live.

\section{RESUlt AND DISCUSSION}

\section{A. Attitude Toward Ex-Prisoners}

Based on the findings, the attitude of the community to prisoners/ex-prisoners is not the same. Public attitudes toward deviant behaviour are influenced by the background of the social status of the prisoners, the type of crime that has been committed, and the behaviour of the convicted person before deviation, as well as the attitude of the victims. Regarding the type of crime or deviation that has been committed by inmates, HRW, an officer at correctional institution, stated that the majority of the residents did burglaries or robberies. And he said that it seems to have become a character for them. He exemplified that there have been inmates who were undergoing assimilation outside stole motor vehicles. Another example is a prisoner who have been in and out of correctional as much as 9 (nine) times -since he children- in the same case of theft and extortion, to the extent of Persada Foundation foundation which accommodates former special prisoners for religious Christians and then guided and distributed to work no longer trust to receive and guide him again. The similar response was also submitted by SBR, a guidance officer in Purwokerto correctional institution. He commented that inmates with theft cases are not included in certain coaching activities. The officer stated that activities of skills development that use sharp tools are forbidden because it is often that they hide sharp tools. Similarly, other equipment, such as books in the LP is also often lost. The criminal act of killing was also mentioned as a type of crime that is difficult to be accepted by the public, as talked about by the PST, a prison correctional counsellor. He realised that the general public is difficult to accept the convicted person who commits a crime of murder, in addition to the attitude of rejecting the public against the convicted murder case also there is a feeling of fear of the prisoner. 
Feelings of concern for the convicted murderer also experienced by head of village and the author of this article when interviewing one of the citizens who committed a criminal act of murder and underwent parole. Sense of concern by MKN as head of village can be read from the comments of how it is better to meet the convicted not in his home than meet in his home alone.

However, the social economic background of prisoners influences the community in giving their social response. As revealed by MKN, a head of village. He considered that what IJI (the perpetrator) did was a calamity only as IJ comes from a decent family and IJ is also an activist on campus. The social response of the community was also felt directly by the IJ a convict who gets a parole. When IJ was in the prison his fellow villagers visited him and usually with many of them. In every Qur'anic recitation in the village, they always informed others that even though he was in the LP but he still continues to read Qur'an. Now that he is back in the community, they also treat him well. Even with his status as an "alumnus" of Nusa Kambangan he is "feared" by the groups that often make trouble, at least to bring their mental down. It is assumed that he can bring in my fellow "alumni" of Nusa Kambangan who are notorious as big guy in crime world. The similar event was also conveyed by RWN, a convict of money counterfeiting, who at that time was undergoing free leave. He related to the attitude of society towards him when he was back among them. His presence back in the community was actually greeted by people. Probably because for two periods he served as the village chief, so he was considered an elder and when he was a soldier once served in trouble spots in West Papua and East Timor he never committed a disciplinary offense until his retirement.

Communities' reaction to prisoners/ex-prisoners is affected by their attitude or their past before committing the crime, as KWT notes a neighbour of a rapist. KWT told that there was no one from his village isolating $\mathrm{S}$ (convicted) as they always invite him to be active again in village activities. It is due to they were in the knowledge that $\mathrm{S}$ was a quiet good young man and never made trouble. They were very surprised when they heard that $\mathrm{S}$ rapped and then sent to Nusa Kambangan. The similar experience also expressed by MK, a head of village, on one of his citizens who killed his own girlfriend. He stated IJ (a convicted person on parole) was actually an intelligent child and from a prominent family in this village, was a student at a state university in Purwokerto. To anticipate the occurrence of things that are not desirable especially the sense of resentment from the victim's family who happened to be his neighbour, the head of village "plant" people, a seller soup, near the victim's house to get information and without the knowledge of IJ. This is due to he got information that the sister of the victim is very vengeful, but until now nothing there is nothing happened. MK testifies that IJ also re-socializes in all activities of village youth.

Public attitudes towards prisoners/ex-prisoners are not the same. It depends on how the community give meaning to inmates/ex-inmates during their interaction. This is as it is in the three premises of symbolic interactionism theory as follows.

1. Humans act toward something on the basis of the meaning attached to something.

2. The meaning of something develops from or through the interaction between humans in everyday life.

3. Meanings - the meaning is held, used as a reference, and interpreted by someone in dealing with something he faced [4].

Based on this theory, people's attitude towards prisoners/ex-prisoners is influenced by the extent to which the public know them before and after the crime. Public understanding of prisoners/ ex-prisoners can be obtained from interactions in daily life or the extent to which people know them. Community's understanding or giving meaning towards prisoners/ex-prisoners has been used as a point of reference in how they conceive them.

\section{B. Stigma That Never Lost}

The social control that exists within the community in the form of formal punishment is sometimes perceived as inadequate for the community in "punishing" criminal offenders. Rejection from the community often exceeds that of formal punishment. Rejection is often a result of stigma in which the stigmatised are deemed as people who has to be avoided and isolated may affect those who are associated with the targeted [5]. Stigma itself is defined by Thornicroft, Rose, Kassam, and Sartorius as problems of knowledge (ignorance), attitudes (prejudice) and behavior (discrimination) [6] .

The status of deviation becomes "master status", a status seen by others as the most important part of a series of status of a person. Others use cultural factors that are inherent in a "master status" to shape expectations, assumptions of criminal offenders, and decide how to respond. As an example of what if a recidivist applies for a job, it is often his/her status overshadows employ years' consideration [7].

The economic anxiety on how the married ex-prisoners could provide themselves and families with resources for living is something that haunts most of them. SWD, a recidivist of theft crime, revealed that he did do not want to repeat being a robber again, but it was hard for him to get the money to live. While the current job is hard to come by, in order to be self-employed he also needs to have his own resource. The similar commentary was also conveyed by SWK based on his experience so far as a correctional client (exprisoners) coach. SWK stated that the complaints he received from his clients other than family issues such as wives seeking divorce are mostly about the difficulty of finding a job. Complaints about the difficulty of finding employment are also provided by IJ, a former prisoner. IJ told his experience that eventhough had a recommendation from Bob Hasan (a famous businessman who went to jail) to work for a company where Bob Hasan owned stocks, it did not work. The company manager said that Bob Hasan did not have a stake in their 
company anymore. There are still friends of him offered the job as a driver, but he does not have the skill of driving.

Those cases can be explained by theory of causes of deviant behaviour, which is not social class-oriented. Bonger states that economic factors have a major influence in the occurrence of irregularities [8]. Society assessed the perpetrators of deviance acts as people whose norms are not the same with the group, so they are rejected as members of their group. This is what happened when people reject exinmates as they return to live among society. Becker's labelling theory states that deviances occur through social decisions against the individual by the people around him. Labelling theory has two propositions, namely:

1. The social group creates a deviation by making the rule that whoever violates it will result in aberrations.

2. Deviant behaviour is behaviour that people are labelled against [8].

With the attitude of not accepting ex-prisoners, the community has undertaken a social control through social pressure. The stigma for ex-inmates is one form of social control through social pressure. The stigma of the public against ex-inmates is seen from WLY's commentary of a neighbour convicted in a murder case. WLY narrated the story of $\mathrm{S}$ (a prisoner on parole) who often made trouble, especially when there was event in their village. He was a young man who did not have a steady job and the community felt safe after $\mathrm{S}$ went to jail. When $\mathrm{S}$ has finished his jail term, they still greeted him when they met on the street only he himself seemed to feel uncomfortable. And when there was a soccer event in the village for Independence Day, S did not do any commotion anymore as law enforcement officers may still supervise him.

Correctional institution on the one hand is a place of resocialisation of inmates in order to re-integrate harmoniously with the community, but on the other hand it can also provide stigma to prisoners. This is as stated by KW one of the village officials when commenting on the Penal Institution. He states that, among society, there is a view that correctional institution -or many people still call prison- is where the bad guys are. Common people may say that people are put in prisons so they can be cured and society also becomes calmer Similarly, MM of a village apparatus where one of his citizens was a prisoner conveyed his perception of the correctional that although correctional institution in terms of positive is as a place of coaching for people who behave deviant to be better, but there is a negative aspect that is usually when people come out of correctional they become more clever and more brutal in doing evil.

This stigma is one of the things feared by the inmates after they are released from the correctional. It is also expressed by RWN, a prisoner with a theft case. He confessed that after he finishes his jail term, he is going to leave his village because he is ashamed and is afraid people will refuse his presence as he thought people are feared of him. The intention of exprisoners to always conceal their identity in society as former inmate is also revealed by SPB, a correctional office officer, based on his experience during guiding clients of correctional office. Usually when his clients moved their address they do not want to be transferred to correctional office in their area of residence, as they want to hide their identity. They do not want people in the area to know that they are still under the guidance of correctional office.

Stigma, according to Goffman, is a characteristic that makes human as if non-human and makes ordinary people to become tainted, forgotten people.

"Stigma also attaches to personality traits, such as unstable and unstable mental unfairness. Recidivists and psychiatric patients, for example, may be treated as outcasts even though they have a righteous behaviour. Even the families of the stigmatized people may suffer with the stigma [9].

PB's reaction toward a neighbouring ex-inmate reveals this. He stated that he was very surprised with his young neighbour as to why the young man can be a user as well as a drug dealer, notwithstanding the background of his father who can be called as kyai and his mother who is an educator. PB thought that maybe his parents are too busy with their public duties. KR who is also a neighbour of an ex-inmate also expressed similar comments. KR commented that all of people in his village wondered how did it happen as the father often lectures about religion in many places.

Nevertheless there are also optimistic inmates with selfserving attitude as presented by HR, a recidivist, regarding the public's response to him as a recidivist who is also of Chinese descent. HR stated that he was a 9 (nine) times recidivist. Based on his experience when he returned to the community, they did not react much to him. According to him, the important thing is he is not blackmailing in his own environment. He went to jail because of defending a friend and also never made trouble with the neighbours, only once and it was because they disturbed his sister. He extorted Chinese-owned shops only and he thought that as they are already rich he does not feel sorry. HA, a drug case-inmate, had optimistic feeling in returning to the community after leaving the correctional institution. He thought people could accept him back because what I did is not a crime that harms others. The same thing also revealed by SLM a convict case of rape. And now his wife is working as a migrant worker in Saudi Arabia. He attempted to show the community that he can do well and if he is good people will also be kind to him.

Based on the above explanation that examines the background of prisoners/ex-prisoners and the acceptance of society and stigma that never disappeared, the success of Purwokerto Correctional Institution in conducting fostering of prisoners with a correctional system is notable. It is proven with indicators of success rate inmates that can be harmoniously integrated with the community. A study on stigma and discrimination by Geiselhart also shows that considering such cases merely in terms of discrimination would overlook the fact that affected people also have agency 
as they are not simply victims who are at the mercy of societal expectations and existing roles [10].

The success story can be summarized as follows. First, the ex-residents of Purwokerto Correctional Institution can be accepted and integrated with the community, although not completely. This means that in social interaction they are not alienated. But in terms of receiving them as employees, citizens tend to remain insecure. The most dominant reason is that they still have a sense of concern about products produced by ex-prisoners and also tends to still have the principle that if there are still others who have never dealt with the police (committing crime) why they employ people who have ever dealt with the police. Secondly, the acceptance of ex-inmates is influenced by several factors that all do not belong to the correctional institution. The aspects include the types of criminal acts committed, socioeconomic status, status of education and ex-prisoner behaviour prior to criminal perpetrating, attitudes of the victims, and bad stigma in the minds of the community towards the person concerned.

\section{National Resilience in the Guidance of Prisoners}

Resilience is the capacity to absorb shocks and to bounce back into functioning shape, or at the least sufficient resilience to prevent stress fractures or even system collapse [11]. Resilience is therefore an undoubted public good. Resilience was to be attained through a multi-dimensional approach to security, with particular attention given to economic development [12]. However the characteristic of national resilience encompasses the spiritual, mental development and determination to educate the nation and the material physical development of administration of the state [13]. National resilience aims to build spiritual, mental strength that is desire and intention to educate the nation with the objectives of building national resilience [14]. The goal of national resilience is to achieve two things: to be able to maintain the survival and to be able to develop the life of the nation and state of Indonesia.

Coaching prisoners with correctional systems is in harmony and supports national resilience. This is evident in the normative provisions; in this case Law No.12 of 1995 on Corrections and other laws and regulations aligned and supported national resilience. This can be explained as follows [15].

First, it is stated in the consideration of Law No.12 1995 that correctional system is a series of law enforcement that aims to help the prisoners realize their mistakes, improve themselves and not repeat the crime so that it can be accepted back by the community environment, can actively play a role in development, and can live fairly as a good and responsible citizen. Secondly, Article 3 of Law No.12 of 1995 states that the correctional system serves to prepare prisoners of the community in order to integrate healthily with the community so that it can play a role as a member of a free and responsible society. Third, Article 5 states that the correctional system is implemented based on the principle of education and guidance and respect of human dignity. Four, the Decree of Minister of
Justice on Pattern of Correctional states that coaching and guidance in correctional system are undertaken through mental approaches (religion, the Five Principles, and so on) to restore self-esteem as persons as well as citizens and have productive potential for national development. They should be therefore educated (trained) also to master certain skills in order to live independently and be useful for national development.

The Minister Decree also states that the guidance of prisoners is intended to successfully re-establish self-esteem and self confidence and be optimistic about his future during the period of coaching and after completing his penal period; managed to gain knowledge, at least the skills to be able to live independently and participate in national development activities; managed to have the soul and spirit of devotion to the nation and state. The policy also implies that correctional is important not only because it is a means to nurture prisoners and inmates in order to improve the ability of independent living in the midst of society later, but also because it provides state awareness education including to know the rights and obligations, thus correctional means is also a means of education and development.

There are also several principles that show relevance to national resilience. The principles in question include the following. The first principle states that the state must protect and give provision of life so that prisoners can perform their role as good and useful citizens. Prisoners should also be instilled with norms of life and be given the opportunity to reflect on past actions. Inmates can be included in social activities to foster a sense of community life. Work given to prisoners must also be integrated with national development.

The second explanation relates to the implementation of guidance with the correctional system in Purwokerto Correctional Institution followed by Purwokerto Correctional Office and community response to the ex-inmates who have lived in society.

Purwokerto Correctional Institution has tried to carry out the guidance of prisoners with correctional system in accordance with Law no.12 of 1995 on correctional as well as other legislation including principles of correctional as have been explained before. This means that the guidance of prisoners is conducted by the correctional of Purwokerto in the perspective of national resilience, is relevant and supports national resilience.

The institution in conducting the process of fostering the inmates is supported by physical facilities in the form of buildings and their facilities, officers as prisoner coach, and prison guidance program. The building and its facilities have been renovated so as not to characterize as a haunted prison for the sake of further support the process and purpose of fostering inmates. The haunted character of the building will indirectly shape the character of the inmates to become violent and distances his soul from a sense of humanity.

In the early period of imprisonment, coaching has begun to be introduced with activities of personality development that includes the development of religious awareness, the development of national and state awareness, the development 
of intellectual ability (intelligence) and the development of legal awareness.

In the next stage inmates, in addition to continue personality development program, also follow the program of independence building. This program includes skills to support independent businesses, skills to support small industry enterprises, skills developed in accordance with their respective talents, and skills in industry/business/agriculture with medium scaled technology.

There is also a program of working activities, which is the provision of employment to prisoners in accordance with the interests and abilities to get rewards in the form of premiums. This activity has the nature of preventive, educative and productive that strongly supports the formation of inmates with correctional system. These three traits strongly support national resilience. Preventive means that by working, the prisoner will be preserved health and fitness both physical and spiritual, because by working during the day then in the night they will be able to sleep well. Besides avoiding negative deeds, the time will be passed quickly so it is not so saturated waiting for the jail time runs out. It is instructive, meaning that the work done by inmates will be a lesson that is very useful later in the days after leaving the correctional institution. In this case it is expected that inmates will not seek a job but they can open a new job field for themselves, so they will not fall for another criminal act. Be productive means that the work done by inmates will produce a product of goods/services. Because the provision of work is a part of coaching and not just to fill the time, then other parties could also utilize the results of production.

In the later stage, in addition to the previous program, it has also been introduced an assimilation program in the form of contacts or relationships with communities outside correctional institution. The aim of this program is to bring the inmates closer to the nature of human life in the life of the community. In the final stage, the program is in the forms of conditional release and pre-release treatment. This program is fully implemented outside the correctional institution and the authorized institution is correctional office.

Purwokerto Correctional Office implement some types of coaching include religious education, character education, individual and group counselling and counselling, formal education, scouting, vocational education, family welfare education, psychotherapy, literature, psychiatry therapy, and various forms of client healing efforts that have not been included in the correctional institution. In carrying out the above guidance is taken through cooperation with related institutions.

The initial stage of guidance under correctional office includes: taking community research, preparing guidance program plan, implementing guidance program, assessing the implementation of the initial program and preparing advanced stage guidance plan. In the final stage of guidance is correctional office examines and asses the overall outcomes of the implementation of the mentoring program, prepares the client for the end of the guidance period, and considers the possibility of additional counselling services (after care), prepares the final certificate of client guidance, and terminates the client's guidance.

The public's response to ex-inmates, convicted prisoners and free leave who are still under the supervision of correctional office and who have lived in the community, especially for ex-murderers and theft, have accepted them but not completely. It means to coexist with ex-prisoners or does not refuse or isolate convicted person, but to employ them, it seems they have to still consider it very carefully. People still argue that if there are workers who are not convicted or exprisoners, why should employ former inmates. People are still afraid of others' judgment on it if they use the services of exinmates.

Based on the aforementioned matters, it is clear that the guidance of prisoners with correctional system in the normative level as contained in Law No.12 of 1995 and other legislation and ten correctional principles followed by its implementation by correctional agents, in this case is in Purwokerto, looks aligned with and supports national resilience. This means that if the normative provisions and their implementation are in line then the purpose of guiding the prisoners is achieved and it is in line with national resilience.

In the implementation of guidance of prisoners in correctional institution there are obstacles. The constraints in question are physical facilities that are still not perfect as specified as well as human resources in the form of officers for some specifications such as psychiatrists, or doctors and other scholars who are actually needed for coaching inmates. Similarly, the correctional office also experiences obstacles. The obstacles include the lack of funding, the lack of public understanding of the existence of correctional office. Limitations of funds have implications on the nonoptimal implementation of the work program. The lack of public understanding of the existence of Bass has implications for the lack of community control over correctional office performance.

Recognizing the relevance of fostering prisoners with a harmonious and supportive system of national resilience, it seems that such an understanding needs to be consciously affirmed and optimized. This means that in the formation of prisoners with this correctional system public should consciously be given understanding and content about national resilience through guidance and coaching conducted by officers with the support of normative provisions.

\section{CONCLUSION}

Correctional Institution has conducted guidance of prisoners with correctional system in accordance with the normative provisions of Law No.12 of 1995 on Correctional, as well as its implementation regulation. The guidance of convicted persons can be classified in three stages: the first stage, the second, and the third. The next stage is the formation of inmates outside the correctional institution that is implemented by correctional office. Based on indicators of the success of ex-prisoners who have been out of jail and obtained guidance from Purwokerto Correctional Office in integrating harmoniously in society, it can be said to be relatively good enough. This means that the former prisoners can be accepted 
and not excommunicated in the everyday life, but to be employed in a work people tend to still avoid. The most dominant reason so that people are still not ready to hire exprisoners is that there is still a sense of concern about people's judgments on products produced by ex-prisoners and also tends to still have the principle that if there are still others who have never dealt with the police (crimes) why wear people who have ever dealt with police or ex-inmates. In addition to these aspects above acceptance of ex-prisoners is influenced by several factors that lie outside the aspects of Penitentiary. This aspect includes the types of criminal acts committed, socioeconomic status, education and ex-prisoner behaviour prior to deviations, attitudes of the victims, and the stigma in the minds of people against ex-prisoners. In the perspective of national resilience it can be said that coaching prisoners with correctional systems is in harmony and supports national resilience. This is evident from the purpose of guidance of prisoners, as it appears in the normative provisions in this case Law No.12 of 1995 on Corrections and other legislation as well as in its implementation as seen in correctional institution and correctional office in Purwokerto. Correctional institution as non-formal education institutions have conducted education programs for inmates during their time in jail and followed up and monitored further by correctional office for prisoners who get parole, and free before leave benefit who are already return to society.

\section{REFERENCES}

[1] Yunardhani, Rakei. Efektivitas Lembaga Pemasyarakatan di Indonesia. Jurnal Sosiologi, Vol. 15, No. 2, pp.143-149. 2012.
[2] Marzuki ML. Siri': bagian kesadaran hukum rakyat Bugis-Makassar: sebuah telaah filsafat hukum. Hasanuddin University Press; 1995.

[3] Departemen Kehakiman Republik Indonesia. Pola Pembinaan Narapida / Tahanan. BPHN. 1990.

[4] Faisal, Sanapiah. Penelitian Kualitatif, Dasar-dasar dan Aplikasi. Malang: Yayasan Asah Asih Asuh. 1990.

[5] Austin, Regina. "The Shame Of It All": Stigma And The Political Disenfranchisement Of Formerly Convicted And Incarcerated Persons. Columbia Human Rights Law Review, Vol.36, pp. 172-191. 2005.

[6] Thornicroft, Graham; Rose, Diana; Kassam, Aliya; and Sartorius, Norman. Stigma: Ignorance, Prejudice Or Discrimination? British Journal Of Psychiatry (2007), Vol. 190, pp. 19-193. 2007.

[7] Johnson, Allan G. Human Arrangements. An Introduction to Sociology. Harcourt Brace Jovanovich, Publishers. New York. 1986.

[8] Susanto, I.S. Kriminologi. Semarang: Fak. Hukum UNDIP. 1990.

[9] Johnson, Doyle Paul, Teori Sosiologi Klasik dan Modern, Jilid II Gramedia. 1993.

[10] Geiselhart, Klaus. Stigma And Discrimination - An Integrative Perspective: Spatial disparities and their impact on the introduction of an antiretroviral therapy scheme for HIV and AIDS treatment in Botswana. Erdkunde, Vol. 64, No. 1, pp. 33-45. 2010.

[11] Omand, David. Developing National Resilience. The RUSI Journal, Vol. 150, No.4, pp.14-18. 2005.

[12] Caballero-Anthony, Mely. SARS in Asia: Crisis, Vulnerabilities, and Regional Responses. Asian Survey, Vol. 45, No. 3 (May/June 2005), pp. 475-495. 2005.

[13] Susetyo, Heru. Menuju Paradigma Keamanan Komprehensif Berperspektif Keamanan Manusia dalam Kebijakan Keamanan Nasional Indonesia. Lex Jurnalica, Vol. 6, No.1, pp.1-10. 2005.

[14] Purwanegara, Dani. Genesis Ide Ketahanan Nasional (Tannas) Indonesia. Jurnal Ketahanan Nasional, IX: 2, pp. 1-26. 2004.

[15] Anonym. Law of Republic of Indonesia No.12 Year 1995 On Correctional. Jabphnkarta 